\title{
Social Inequalities in Student Employment and the Local Labour Market
}

\author{
Marita Jacob $\cdot$ Maria Gerth $\cdot$ Felix Weiss
}

Published online: 15 April 2020

(C) The Author(s) 2020

\begin{abstract}
This article examines class-specific employment patterns among students in Germany, taking into account how different local labour market conditions affect the quantity and quality of jobs available to students. We argue that the availability of jobs affects social inequalities in student employment. In particular, we expect a stronger correlation between, on the one hand, the rate and quality of student employment and, on the other hand, students' socioeconomic background in towns with a large pool of student labour, due to more competition for (good) jobs. Analysing data from German student surveys, we find that employment rates do not differ by social class background, but there are differences in the quality of their employment in terms of the fit between the job and the field of study. While we find that local labour market conditions affect student employment at a general level, in contrast to our expectation, tighter labour market conditions seem to involve little or no disadvantage for students from less privileged social backgrounds.
\end{abstract}

Keywords Higher education - Student jobs · Social origin · Labour market · Educational inequality

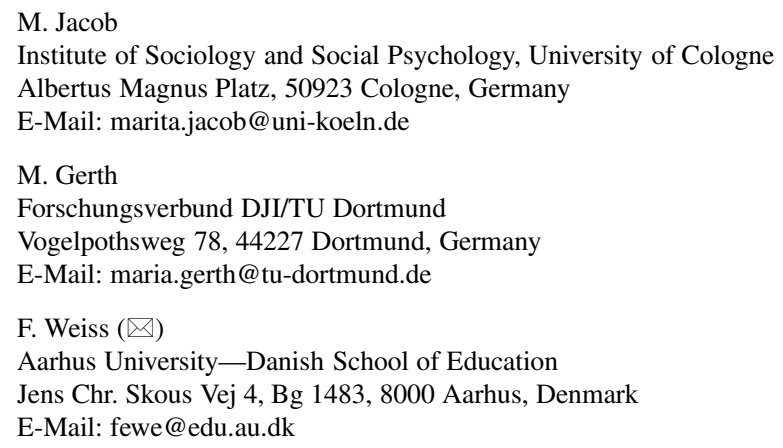




\section{Ungleichheiten nach dem Hochschulzugang: Bedingungen des lokalen Arbeitsmarkts und soziale Ungleichheiten in der Erwerbstätigkeit von Studierenden}

Zusammenfassung Dieser Beitrag untersucht die Abhängigkeit der Studierendenerwerbstätigkeit von der elterlichen sozialen Klasse in Deutschland. Besonderes Augenmerk gilt hierbei den lokalen Arbeitsmarktbedingungen und ihrem Einfluss auf den Umfang und auf die Qualität der Erwerbstätigkeit von Studierenden. Wir erwarten, dass sich die Verfügbarkeit von Stellen auf die soziale Ungleichheit in der Erwerbsarbeit auswirkt. Insbesondere gehen wir davon aus, dass der Zusammenhang zwischen der sozialen Herkunft mit dem Umfang und mit der Qualität von Erwerbsarbeit höher korreliert ist in Kontexten mit einem hohen Studierendenanteil, da hier die Konkurrenz um (gute) Stellen intensiver sein sollte. Auf Basis der Daten des Konstanzer Studierendensurveys finden wir keine Unterschiede nach sozialer Herkunft in der Häufigkeit der Erwerbstätigkeit, allerdings in der Qualität der Arbeit gemessen mit der Frage, ob sie einen inhaltlichen Zusammenhang mit dem Studium hat. Mit Hinblick auf die lokalen Arbeitsmarktbedingungen finden wir zwar einen Einfluss auf die Erwerbstätigkeit im Allgemeinen, verschärfte Wettbewerbsbedingungen scheinen entgegen unserer Erwartungen aber kein Nachteil für Studierende mit einem nichtprivilegierten sozialen Hintergrund zu sein.

Schlüsselwörter Hochschulbildung · Studierendenerwerbstätigkeit · Soziale Herkunft · Arbeitsmarkt · Bildungsungleichheit

\section{Introduction}

In many countries, enrolment in higher education is still socially selective ${ }^{1}$. With increasing shares of a cohort enrolling into higher education and a more heterogeneous student population in higher education, more and more scholars have pointed to important "qualitative" inequalities among university students, such as combining education with work (for Germany see for example Jacob et al. 2018; for the US see Scott-Clayton 2012; Weiss and Roksa 2016). In many countries, students spend a considerable amount of time working in parallel to their studies. For Germany, the most recent social survey of students (21. Sozialerhebung) shows that employment is common during higher education: $68 \%$ of all students in higher education in 2015 worked during term time. Moreover, this proportion is similar for students from different social backgrounds, with figures of $69 \%$ and $64 \%$ for the lowest and highest educated origin groups in the survey respectively (Middendorff et al. 2017, p. 60). However, students from less privileged social backgrounds more often state that they have to work in order to support themselves and are more likely to work several days per week (Middendorff et al. 2017, p. 62). Working during term time can result in less time spent on education, and the negative associations between

\footnotetext{
1 Evidence for Germany can be found, for example, in Hillmert and Jacob (2010), Mayer et al. (2007) or Weiss and Steininger (2013).
} 
employment and educational outcomes are well known (for reviews see Neyt et al. 2017; Pascarella and Terenzini 2005; Riggert et al. 2006). Hence, differences in student employment patterns by social origins have been identified as an important dimension of inequality in higher education.

Several previous studies have explained students' employment as the result of a rational decision and assumed that students' choice of whether to work or not is dependent on their social origins (e.g. Callender 2008; Demeulemeester and Rochat 2000; Roksa et al. 2009). From this perspective, social differentials in student employment patterns can be explained by greater financial need, making work a necessity among students from lower-class backgrounds. By contrast, students from higher-class backgrounds can choose whether or not to work and may only take a job if it provides additional qualifications that will enhance later labour market opportunities. We argue that this decision-based approach fails to take into account how this choice is restricted by the availability of different jobs within the local labour market. There are remarkable local and regional variations in student employment patterns; for example, students in the former East Germany are less likely to work than those in western Germany, and employment rates of towns with full research universities or technical universities range between, for instance, $79 \%$ in Cologne and $49 \%$ in Mannheim (Middendorff et al. 2017, p. 61). In this article, we examine such local and regional variations in student employment rates in greater detail. We argue that as well as regional variations in conditions that may have an impact on students' need to work, such as housing costs in different cities, local labour market opportunities for students vary greatly among university locations.

In particular, we build on existing theoretical explanations for why higher education students from different social backgrounds work whilst studying by factoring in the local availability of student jobs. Job opportunities are highly dependent on the industrial structure surrounding the campus. In some German regions, student employment opportunities are limited to mainly unskilled manual or service jobs. In other regions, it is easier for students to find employment related to their field of study; some employers even use this as a recruitment strategy, with students transitioning into full-time positions upon graduation. This leads us to ask the following questions: Do student employment rates, and the quality of students' jobs in terms of relevance to their field of study, differ according to social origin? And how is this relationship conditioned by local labour market conditions and structures?

In our empirical analyses, we use data from the German student survey (Studierendensurvey) conducted by researchers at the University of Konstanz, covering over 18,000 students in more than 20 cities. To characterise local labour market conditions, we draw on the overall unemployment rate and two measures for competition for jobs among students at the regional level, derived from official statistics and figures compiled by the German Institute of Employment Research (IAB). Consistent with previous research, we do not find large differences in average employment rates by social origins, but we do find an association between students' social background and job quality - something that has been widely neglected in previous research among higher education students in Germany. In addition, our findings show that local labour market contexts influence students' employment patterns. However, con- 
trary to our expectations, local labour markets have little effect on the link between social origins and the probability of employment.

\section{The Impact of Local Labour Market Conditions on Social Inequality in Student Employment Patterns}

Developing a theoretical understanding of contextual differences in social inequality needs three perspectives: first, we have to explain why there are social origin differences in the needs and incentives to take up paid work during one's studies. Second, we have to take into account local conditions that structure the availability of jobs for students. Third, we need to explain how these two levels interact, i.e. how social inequalities in student employment patterns are affected by local labour market conditions. In the following, theoretical discussion of each of these three elements is used to derive hypotheses that can be tested through analysis of empirical data.

\subsection{Why Do Some Students Work While Others Do Not? Work Between Financial Necessity and Competence Development}

Inequalities in terms of how social origins affect the quantity and quality of student employment have been widely documented in a wide range of industrialized, Western countries (Bozick 2007; Callender 2008; Canabal 1998; Demeulemeester and Rochat 2000; Metcalf 2003; Moreau and Leathwood 2006; Nienhüser 2001; Roksa et al. 2009; Roksa and Velez 2010; Sanchez-Gelabert et al. 2017; Weiss and Roksa 2016).

In order to explain such differences in labour market participation we need to understand students' rationales for entering paid employment. On the one hand, working while studying may have a negative impact on academic results (Behr and Theune 2016; Hovdhaugen 2015; Neyt et al. 2017; Triventi 2014); on the other hand, there may be several benefits. These benefits can be divided into immediate monetary returns and long-term returns of work experience gained from on-the-job training that will pay off upon post-graduation labour market entry (Passaretta and Triventi 2016; Sanchez-Gelabert et al. 2017; Weiss et al. 2014). Although the former can be gained from any form of paid work, the latter requires the job to qualify the student for later entry to his or her chosen professional field-something we refer to as "qualification-related" returns from "quality" jobs (for other work-based benefits, see for example Creed et al. 2015). As such, it is necessary to consider not only the question of whether or not students work but also the type of job.

Students' need and/or willingness to work may be affected by their social origins. First, students from lower-class backgrounds generally receive fewer monetary resources from their parents to cover their living expenses (Erikson and Jonsson 1996). In Germany, this may be somewhat mitigated by a public financial aid scheme $(B A f \ddot{o} G)$. Entitlement to this financial aid depends on parental income, on the student's family situation, for instance providing additional support to students from single-parent families, and on the number of siblings. $B A f \ddot{o} G$ thereby buffers the financial needs of students from low-income families, but is partly loan-based and does not cover the full costs of higher education in all cases. Hence, students in the 
lower-middle classes might more frequently have to rely on employment to cover their living expenses, as this group is caught in the middle, with their parents' income being above the threshold for receiving public aid, but too low to provide a meaningful contribution to their living expenses (Brandt and Apolinarski 2018). Nevertheless, many students from lower classes work if the financial aid they receive is not sufficient to fully cover their living expenses or if they are concerned about having to repay heavy debts incurred through student loans. By contrast, students from higher classes often do not have to work for subsistence and can therefore afford only to accept jobs with qualification-related returns that complement their academic skills. Second, assuming that avoiding intergenerational downward social mobility is a highly prioritised incentive in students' educational decisions (for a theoretical discussion see Stocké 2019; for a recent empirical test on secondary education in the German context see Zimmermann 2019), jobs with qualificationrelated returns help with this aim as they can open doors to attractive positions after graduation $^{2}$.

Last but not least, we assume class differences in terms of opportunities to enter different kinds of jobs related to different social and cultural capital. Students from privileged socio-economic backgrounds are more likely to gain access to "quality" jobs that provide valuable qualifications through their parents' networks (for a review see Mouw 2006); this is particularly true for student jobs, which are often not subject to the normal regulations requiring an open and competitive recruitment process and for which recruitment processes are less formalized compared with full-time employment in the highly skilled sector. In addition, students from higher classes might be preferred by employers because they are familiar with the cultural expectations and "soft skills" of a high-skilled working environment (Farkas 2003). Lower-class children, on the other hand, lack such resources and may lose the competition for high-skilled jobs. Consequently, they more frequently have to work in the unskilled sector.

To sum up, students from affluent backgrounds often do not have to work as a means of subsistence and we therefore expect overall student employment rates for this group to be lower. When students from such backgrounds do opt to work, we expect other, non-monetary aspects to be important in this decision and that they will only accept "quality" jobs, such as jobs related to their field of study. Furthermore, they often have the edge over students from less privileged families in terms of opportunities to enter high-quality employment. As a consequence, we expect those from affluent backgrounds to be more likely to hold "quality" jobs whereas their less affluent peers settle for jobs providing only short-term monetary returns (social origin hypothesis).

\footnotetext{
2 There are further arguments related to the motive of avoidance of downward mobility that can explain why children from privileged socio-economic backgrounds might not be willing to accept (non-qualifying) work: these students or their parents might perceive working during one's studies as temporary downward mobility or as a signifier of low-status groups, and parents do not want their children to be socialized in an environment of unqualified workers. As such, the perception of possible "risks" of unskilled work as harmful to later careers and the attainment of a service-class position is higher among service-class than among working-class students.
} 


\subsection{The Moderation of Social Origin Effects on Students' Labour Market} Participation by Local Labour Market Contexts

For Germany, policy reports show that students' labour market participation rates differ enormously between different university cities. According to the social survey of students 2017, Cologne, Frankfurt, Siegen and Ludwigsburg have the highest student employment rates among all university locations. Here, at least $78 \%$ of students worked during term time, compared with only $63 \%$ in the eastern part of Germany (Middendorff et al. 2017, p. 62). Similar patterns were observed in the previous survey in 2012, leading the authors to discuss differences in living costs that may explain the disparities in student employment rates (Middendorff et al. 2017, p. 354f.). Indeed, based on the results from Middendorff et al. (2017) regarding student housing costs ("WG-Zimmer") and student employment rates, the two variables have a linear correlation of 0.43 at the level of university towns (Pearson's r, own calculation based on 58 university towns with information available on both variables).

However, one can also approach the matter from the opposite direction: besides context-specific living costs, the possibility of finding a job, and specifically of finding a "quality" job to gain additional qualifications, depends on the availability of such jobs in the vicinity of university campuses, as well as on their accessibility to students from different social backgrounds. Hence, local labour markets around campuses affect the two aforementioned dimensions of student employment as context characteristics: on the one hand, differences in the overall availability of student employment, and on the other hand, the varying quality of the jobs available.

Our theoretical considerations are based on labour market supply and demand and on recruitment and allocation processes. Both employers offering jobs and student jobseekers want to maximise their utility: employers want to recruit suitable and cheap student workers (that may or may not become future regular employees), whereas students want to earn money and/or gain qualification-related returns. In tight labour markets with few per capita student jobs available, employers can pick and choose between applicants when recruiting. In this case, the bargaining power is located with the employer, who can offer lower wages. Some students need to work to make ends meet and will therefore accept even bad job offers. By contrast, students with loftier social origins may withdraw, at least from the unskilled, lowpaid labour market, which offers no qualification-related returns, as they do not need to work. For those students who do work, those from a higher social background have an advantage in the recruitment process as they might appear more suitable to employers due to their social and cultural capital (see Sect. 2.1). In labour markets with more jobseekers than vacancies, employers can choose between a large number of applicants, potentially tipping the scales even further in favour of students from higher-class backgrounds in recruitment to high-quality jobs. Summing up, we expect social origin effects on employment rates and job quality to be more pronounced in crowded labour markets (labour market hypothesis). 


\subsection{Student Employment in Germany: Institutional Context}

In Germany, enrolment in higher education is usually a full-time commitment and working should therefore not be the main status; work must be part-time and has to fit around the student's academic schedule. The share of part-time students remains low, despite rising from $3.7 \%$ in 2005 (Statistische Ämter des Bundes und der Länder 2007) to 6.4\% in 2012 (Statistische Ämter des Bundes und der Länder 2014, p. 44).

Besides work and financial support from their parents, students can apply for support under the German Federal Training Assistance Act (in short BaföG; BMBF 2012). The amount is determined via means testing based on parental and own income and assets, and usually comprises both a direct grant and a loan component. However, coverage has been low, although it has increased in recent years. In 2016, for students in single-person households, who usually benefit most from the programme, BAföG studentships contributed on average $17 \%$ to the income of students with non-academic parental origins and $6 \%$ to the income of students from an academic background (Brandt and Apolinarski 2018). Gainful employment, on the other hand, contributed on average $31 \%$ (non-academic) and $24 \%$ (academic) respectively (Brandt and Apolinarski 2018). Hence, although public financial support can be expected to somewhat reduce student employment rates and the related inequalities, as both the coverage and the average amount are not very high, many students work (in addition to the BAfö $G$ support) to cover their living expenses.

Typical side jobs for students (and for other employees working few hours) are those regulated in the so-called "Mini job" sector for marginal jobs with reduced social security contributions. Mini jobs are defined by a wage threshold, e.g. in 2000 (when a significant amount of the data we are analysing was collected) no more than $325 €$ per month, or by low work intensity, e.g. no more than $15 \mathrm{~h}$ per week in 2000 . If employment exceeds both of these limits, social security contributions increase sharply. Compared with other applicants and employees in marginal jobs, there are additional favourable regulations for students: for full-time students working less than $20 \mathrm{~h}$ per week during term time, social security contributions are further reduced or even waived (Werkstudentenprivileg). ${ }^{3}$

As we argued above, job opportunities depend on local labour market conditions. It should be highlighted that economic prospects and labour market conditions vary remarkably in Germany. For example, for the early 2000s, unemployment rates in western Germany ranged in 2003 from 6.2\% in Baden-Württemberg in the south to $13.2 \%$ in the city-state of Bremen in the north of Germany. In eastern Germany, rates were even higher, with unemployment in the state of Sachsen-Anhalt at $20.5 \%$ (Bundesagentur für Arbeit 2004). In addition, these state-level differences cover significant variation at a more local level.

\footnotetext{
3 See the verdict of the Federal Social Security Court (Bundessozialgericht) 11.11.2003-B 12 KR 24/03 R. There are some exceptions, e.g. those working mainly in the evening or at weekends. Outside term time, students are allowed to work more than $20 \mathrm{~h}$ per week for a maximum of 26 weeks per year.
} 


\section{Data, Variables and Methods}

In order to test our hypotheses, we utilise survey data from the Konstanz student survey. This cross-sectional mail survey has been conducted every two or three years since 1983 and is funded by the Federal Ministry of Education and Research (Bundesministerium für Bildung und Forschung, BMBF). When analysing general labour market participation, we use the waves: 2000/2001, 2003/2004, 2006/2007, 2009/2010, 2012/2013 and 2015/2016 (Bargel et al. 2005, 2003; Georg and Ramm, 2018). The two oldest survey waves containing specific questions on job quality (2000/2001 and 2003/2004) are used for testing our theoretical hypotheses about student job quality: all working students were asked if the job's content is related to their studies ${ }^{4}$. The student survey covers a sample of universities selected to include all major types of university, of different sizes and in different federal states. At these universities, a random sample of 24,000 students was drawn in the 2000/2001 wave. Sample sizes were increased to 28,000 in the $2003 / 2004$ wave and again to almost 38,000 in the 2015/2016 wave. Response rates were around 35\% in the 2000/2001 and 2003/2004 waves, decreased to less than 30\% in the following waves and dropped below $20 \%$ in the $2012 / 2013$ wave. This translates into respondent numbers between 4884 in 2012/2013 and 9975 students in 2003/2004 (Multrus 2016). After applying listwise deletion, the subsample we use for our analyses of local labour market contexts across all waves consists of 31,489 students in 22 German cities, covering very different regional contexts in the eastern and western parts of Germany. Descriptive statistics of our sample are shown in Tab. 1.

The survey questionnaire includes several questions on study conditions. Moreover, some information on student employment is provided. In the empirical analyses, we use two different dependent variables. The first of these variables is whether or not a student was employed during term time. ${ }^{5}$ We exclude respondents indicating that they spent time working as a research or teaching assistant at their university during the current semester to prevent obscuring the effects of local labour market conditions through differences in university budgets ${ }^{6}$. We operationalize job "quality", our second dependent variable, as the respondent's self-assessment of the

\footnotetext{
4 The original question in German was "Falls Sie in diesem Semester während der Vorlesungszeit erwerbstätig sind: Hat diese Arbeit einen Bezug zu Ihrem Studium?" [If you are gainfully employed during term time in the present semester: is your work related to your studies?].

5 We assume that working during term time is more consequential than working during holidays as the former might be more detrimental to students' academic success.

6 Analyses including respondents working as research or teaching assistants reveal similar results and are available from the authors upon request. We decided to exclude teaching assistants from our main analysis as the availability of such positions is not determined by the general labour market. German universities are funded by the federal states (Länder), affecting university budgets as well as financial and staff matters (Hartwig 2006). They differ in the extent of third-party funding for research (Hornbostel 2001). As the availability of both teaching assistant and research assistant positions depends on these resources, which are not related to general local labour market conditions, we decided to exclude such on-campus jobs. As a consequence, we underestimate overall student employment and we may also underestimate social differences in our analyses, assuming that university jobs can be counted as high-quality jobs with high qualification-related returns. Furthermore, recent research indicates that there are no social inequalities in access to these jobs (Jacob et al. 2018).
} 
Table 1 Descriptive statistics of our sample. (Source: Student Survey Konstanz, 2000/2001, 2003/2004, 2006/2007, 2009/2010, 2012/2013, 2015/2016 waves; own calculations)

\begin{tabular}{|c|c|c|c|c|}
\hline & & Mean* & SD & $\begin{array}{l}\text { Missing values } \\
n / \% \text { (of } 42,205 \text { ) }\end{array}$ \\
\hline Macro data & & & & \\
\hline Unemploymen & & 11.0 & 4.2 & $0 / 0.0$ \\
\hline Students/worki & ppulation & 0.2 & 0.8 & $0 / 0.0$ \\
\hline Marginal empl & nt/students & 1.1 & 0.5 & $0 / 0.0$ \\
\hline Local rent rate & & 6.1 & 2.1 & $633 / 1.5$ \\
\hline Micro data & & & & \\
\hline Employment & & 47.9 & - & $6,785 / 16.1$ \\
\hline Parental & Working class & 6.4 & - & $961 / 2.3$ \\
\hline occupation & Intermediate class & 43.2 & - & \\
\hline & Service class & 50.4 & - & \\
\hline Age & & 24.1 & 4.6 & $95 / 0.2$ \\
\hline Number of chil & & 0.8 & 0.4 & $288 / 0.7$ \\
\hline Male & & 42.2 & - & $93 / 0.2$ \\
\hline Marital status & Married/divorced/widowed & 5.5 & - & $159 / 0.4$ \\
\hline & Unmarried, with partner & 51.7 & - & \\
\hline & Unmarried, no partner & 42.8 & - & \\
\hline Internship & & 4.4 & - & $99 / 0.2$ \\
\hline Previous worki & perience & 1.4 & - & $833 / 2.0$ \\
\hline Previous vocati & training & 13.8 & - & $0 / 0.0$ \\
\hline Subject & Languages and culture & 16.5 & - & $158 / 0.4$ \\
\hline & Psychology & 2.3 & - & \\
\hline & Education/social work & 8.5 & - & \\
\hline & Sports & 1.5 & - & \\
\hline & Law & 5.6 & - & \\
\hline & Social science & 5.0 & - & \\
\hline & Business & 14.8 & - & \\
\hline & Maths/natural science & 16.8 & - & \\
\hline & Medicine & 8.9 & - & \\
\hline & Agricultural science & 1.9 & - & \\
\hline & Engineering science & 14.6 & - & \\
\hline & Arts & 2.7 & - & \\
\hline & Other & 1.0 & - & \\
\hline University & & 75.1 & - & $0 / 0.0$ \\
\hline Number of sem & & 5.4 & 4.3 & $971 / 2.3$ \\
\hline Upper & Allgemeine Hochschulreife & 91.3 & - & $634 / 1.5$ \\
\hline secondary & Fachgebundene Hochschulreife & 2.1 & - & \\
\hline $\begin{array}{l}\text { school } \\
\text { certificate }\end{array}$ & Fachhochschulreife & 6.6 & - & \\
\hline School grade (s & ardized) & 0.0 & 1.0 & $446 / 1.1$ \\
\hline
\end{tabular}

$N: 31,489$

*For categorial variables entries refer to percentages instead of means 
relationship between their job and their studies. This is measured on an ordinal scale from 1 (very closely related) to 4 (not at all related). Because we expect social origin differences to be strongest for jobs that are not at all related to students' field of study, we decided to apply a dichotomous variable distinguishing between jobs that are not at all related to the student's field of study [i.e. category 4 of the ordinal scale] and jobs that are to at least some extent related to the student's field of study [i.e. categories 1-3 of the ordinal scale]. We are specifically interested in how these two concepts vary with our main independent variables, local labour market conditions and social origins. Our hypotheses build on monetary resources that parents can provide. We thus decided to operationalize parental class as the highest current occupational status out of both parents. Parental status was measured in the dataset as the detailed occupational status ${ }^{7}$. Students were questioned on the hierarchical position in the workplace and the employment relationship (defined by the social insurance status) of their parents using 13 categories, which we code into three categories: "working class", "intermediate class" and "service class". Unfortunately, the data do not include information about students' living situation, such as whether they live alone, with a partner or in the parental home.

We use three local labour market indicators that represent different characteristics of the market for student labour:

- The local unemployment rate, as an indicator of the overall labour market situation. This is expected to affect students' opportunities to find employment, as, in markets with a high unemployment rate, other jobseekers start competing with students for unstable or short-term jobs.

- The ratio of the size of the student population to the size of the working population, as an indicator of competition among students for jobs.

- The ratio of the number of marginal jobs to the number of students, to measure the labour market structure as well as the possible competition among students in this particular sector of mainly unskilled jobs.

"Unemployment rate" refers to the percentage share of unemployed in the civilian labour force for each city. This information is provided by INKAR $^{8}$ and relies on data from the Statistics Department of the Federal Employment Agency ("Statistik der Bundesagentur für Arbeit") and the Eurostat regional database. "Student population" is the sum of students enrolled in all the higher education institutions in each of the cities we study and can be found at the Federal Statistical Office (Destatis) $)^{9}$ "Working population" is a measure of all employees who are subject to social insurance requirements. "Marginal jobs" (geringfügige Beschäftigung) are defined by law and are typically jobs that are paid less than $450 € /$ month, which has consequences for taxation and social insurance payments. Both indicators are

\footnotetext{
7 The original German variable closely corresponds to the concept "Stellung im Betrieb", which was used as a classification in official German statistics until recently.

8 "Indikatoren und Karten zur Raum- und Stadtentwicklung in Deutschland und in Europa", Federal Institute for Research on Building, Urban Affairs and Spatial Development, Bonn. Available at www.inkar. de.

9 https://www-genesis.destatis.de/genesis/online.
} 
taken from the Statistics Department of the Federal Employment Agency. ${ }^{10}$ As these indicators vary over time, we measure them for each of our observation years and match the information to the corresponding cities (i.e. university contexts) in the respective wave of the Konstanz student survey.

In order to correct our estimates on the macro level for local price levels, especially housing prices, we include the "medium rent index" for flats for each city in our models. ${ }^{11}$ This index not only approximates students' housing expenses, but also strongly correlates with overall prices and living expenses in each particular context. On the individual level, we include several socio-demographic variables in the models: gender, age, marital status (single, married, partner), and children. To model previous education and current studies, we use information given on school grades, the type of school-leaving certificate (full versus restricted to lower-tier institutions (Fachhochschulreife) versus vocationally restricted school degree), studying in a first- or second-tier institution of higher education, field of study divided into 13 categories, and the study progression (semesters started). We account for whether or not vocational training was undertaken before enrolment, and for previous work experience (in the form of internships or regular employment).

We model differences between contexts by applying multilevel regression, with students as level 1 units (31,489 for employment for all waves, 13,721 for employment for the 2000/2001 and 2003/2004 waves and 6687 for our analysis of students' job quality) and cities in given years as level 2 units (40 cities for job quality, most of them for several years) for our analyses regarding job quality. To model the expected differences in the influence of local labour market conditions by social origin, we specify interaction effects with each labour market indicator. We estimate linear probability models. This strategy is preferable to logit models in estimating and interpreting interaction effects that are of primary interest for our hypotheses concerning social differences in varying local labour market conditions (Mood 2010). The models for job quality are also linear two-level models. We estimated random intercept and random slope models applying maximum likelihood estimation $^{12}$. This decision is supported by likelihood ratio tests that indicate the best model fit for the random intercept model. All metric variables are centred at their grand mean (Gelman and Hill 2007).

\footnotetext{
10 Note that these figures were revised in 2014; thus, our indicators for 2015 rely on a different definition. Data prior to this revision are taken from https://statistik.arbeitsagentur.de/Navigation/Statistik/ Statistik-nach-Themen/Beschaeftigung/Beschaeftigte/vor-der-Datenrevision/vor-der-Datenrevision-Nav. html whereas data after the revision can be accessed via https://statistik.arbeitsagentur.de/Navigation/ Statistik/Statistik-nach-Themen/Beschaeftigung/Beschaeftigte/Beschaeftigte-Nav.html (accessed 16 September 2019).

11 The local rent data was provided by "Immobilienverband Deutschland IVD Bundesverband der Immobilienberater, Makler, Verwalter und Sachverständigen e. V.", Littenstraße 10, 10179 Berlin, Germany and can be found in the following issues of the "Immobilienpreisspiegel" 2000/2001, 2003/2004, 2006/2007, 2009/2010, 2012/2013, 2015/2016. We used information for housing built before 1948 .

12 The model we estimate has random slopes for both dummy variables: "intermediate classes" and "lower classes", which are constraint to be equal. It is thus estimated as $y_{i j}=\beta_{\mathbf{0}}+\beta_{1} x_{1 i j}+\beta_{\mathbf{2}} x_{\mathbf{2} i j}+\beta_{\mathbf{3}} x_{\mathbf{3} i j}+$ $\ldots+\beta_{k} x_{\mathbf{k i j}}+u_{0 j}+u_{23} x_{2 i j}+u_{23} x_{3 i j}+e_{0 i j}$

where $\mathrm{i}$ is individual and $\mathrm{j}$ is context.
} 


\section{Empirical Results}

\subsection{Descriptive Results}

Our descriptive analyses of student employment are in accordance with previous results and support our hypotheses. First, we only find small differences in student employment rates according to parents' occupational status (Tab. 2). However, all percentages are in line with our expectations both for the subsample 2000/2003 (i.e. waves 2000/2001, 2003/2004) and for all waves (i.e. 2000/2001, 2003/2004, 2006/2007, 2009/2010, 2012/2013, 2015/2016). In the subsample 2000/2003, which allows for a differentiation of the type of work as in Sect. 4.2 of this article, the smallest proportion of students not working (in a job off-campus) is found among students with a working-class background $(48 \%)$ whereas the highest proportion is found among students with service-class parents (53\%), with students from intermediate classes in between (50\%). However, although the proportion working in fieldunrelated, low-quality jobs is highest among children from the working class, the proportion working in field-related jobs is highest for students whose parents are of the service class.

We observe a great deal of variation between different cities in the share of students who are employed. In urban centres and metropolitan regions, typically $60 \%$ or more of students are gainfully employed. In eastern Germany, we observe lower rates of student participation in the labour force. However, urbanisation and the East-West divide are not sufficient to capture the full diversity, as there are also smaller cities with high employment rates and some cities in western Germany have employment rates markedly below $40 \%$, which are as low as those typically found in eastern cities. There is also remarkable regional variation in the type of jobs, i.e. in the degree to which students' jobs are related to their field of study. As a general tendency, larger cities have a higher share of students working in highquality jobs ${ }^{13}$. Further descriptive analyses indicate inconsistent results regarding

Table 2 Student employment according to parental occupational status. (Source: Student Survey Konstanz, sample 2000/2003: 2000/2001 and 2003/2004 waves; all waves: waves 2000/2001, 2003/2004, 2006/2007, 2009/2010, 2012/2013, 2015/2016; own calculations)

\begin{tabular}{|c|c|c|c|c|c|c|}
\hline & $\begin{array}{l}\text { Sample } \\
2000 / 2003\end{array}$ & $\begin{array}{l}\text { All } \\
\text { waves }\end{array}$ & $\begin{array}{l}\text { Sample } \\
2000 / 2003\end{array}$ & $\begin{array}{l}\text { Sample } \\
2000 / 2003\end{array}$ & $\begin{array}{l}\text { Sample } \\
2000 / 2003\end{array}$ & $\begin{array}{l}\text { All } \\
\text { waves }\end{array}$ \\
\hline $\begin{array}{l}\text { Parents' oc- } \\
\text { cupational } \\
\text { status }\end{array}$ & $\begin{array}{l}\% \text { Not } \\
\text { working }\end{array}$ & $\begin{array}{l}\% \text { Not } \\
\text { work- } \\
\text { ing }\end{array}$ & $\begin{array}{l}\text { Working, } \\
\text { related to } \\
\text { studies }\end{array}$ & $\begin{array}{l}\text { Working, unre- } \\
\text { lated to studies }\end{array}$ & $n$ & $n$ \\
\hline Working class & 48.3 & 50.5 & 29.8 & 22.0 & 884 & 2,024 \\
\hline $\begin{array}{l}\text { Intermediate } \\
\text { class }\end{array}$ & 50.0 & 51.2 & 30.8 & 19.3 & 5,675 & 13,590 \\
\hline Service class & 52.6 & 53.1 & 30.5 & 16.9 & 7,277 & 15,875 \\
\hline Total & 51.3 & 52.1 & 30.5 & 18.2 & 13,836 & 31,489 \\
\hline
\end{tabular}

$N: 31,489$ students

13 Owing to restrictions regarding data access, we cannot disclose universities and therefore cannot name examples or give a full table for the proportions of students working by city. 
social inequalities in student employment by university location. Although there are cities where social origin differences are in line with our expectation that students from higher-class backgrounds work less and are more likely to have jobs related to their studies than students from the working class, others show no clear differences or even reversed inequality, i.e. students with higher-class backgrounds are more likely to work more often and more likely in jobs unrelated to their field of study than their peers from the lower classes. ${ }^{14}$ In the following multivariate analyses, we test whether specific local labour market conditions, i.e. availability and competition, respective accessibility, are systematically related to students' employment and how they affect social inequalities in employment.

Table 3 Student labour market participation-2000/2001 and 2003/2004 waves. (Source: Student Survey Konstanz, 2000/2001 and 2003/2004 waves; own calculations)

\begin{tabular}{|c|c|c|c|c|}
\hline & Model 1 & Model 1a & Model 1b & Model 1c \\
\hline \multicolumn{5}{|c|}{$\overline{\text { Parents' occupational status (ref_-parents: service class) }}$} \\
\hline Parents: working class & 0.01 & 0.01 & 0.01 & 0.01 \\
\hline Parents: intermediate class & 0.01 & 0.01 & 0.01 & 0.01 \\
\hline \multicolumn{5}{|l|}{ Local labour market characteristics } \\
\hline Unemployment rate & $-0.01 * * *$ & $-0.01 * * *$ & - & - \\
\hline Students/working population & $-0.39 * *$ & - & -0.28 & - \\
\hline Marginal employment/students & -0.02 & - & - & 0.03 \\
\hline \multicolumn{5}{|l|}{ Interaction: local context* parents' class } \\
\hline $\begin{array}{l}\text { Unemployment rate* working class par- } \\
\text { ents }\end{array}$ & - & 0.00 & - & - \\
\hline $\begin{array}{l}\text { Unemployment rate* intermediate class } \\
\text { parents }\end{array}$ & - & 0.00 & - & - \\
\hline $\begin{array}{l}\text { Students/working population* working } \\
\text { class parents }\end{array}$ & - & - & 0.15 & - \\
\hline $\begin{array}{l}\text { Students/working population* intermedi- } \\
\text { ate class parents }\end{array}$ & - & - & 0.20 & - \\
\hline Marginal/students* working class parents & - & - & - & -0.07 \\
\hline $\begin{array}{l}\text { Marginal/students* intermediate class } \\
\text { parents }\end{array}$ & - & - & - & -0.02 \\
\hline Constant & $0.53^{* * *}$ & $0.54^{* * *}$ & $0.53^{* * *}$ & $0.53^{* * * *}$ \\
\hline Var (parental status) & 0.00 & 0.00 & 0.01 & 0.01 \\
\hline Var (residual) & 0.22 & 0.22 & 0.22 & 0.22 \\
\hline
\end{tabular}

Two-level random intercept linear probability model, random slopes for parents' occupational status Level 1: cities at time points $\left(N_{1}=40\right)$, level 2: students $\left(N_{2}=13,721\right)$

Models also include gender, age, marital status, children, school grades, the type of school-leaving certificate, studying in the first or second tier of higher education, field of study, number of semesters, previous vocational training and previous work experience

Full estimation results are presented in Tab. 6 in the Appendix

$+p<0.1, * p<0.05, * * p<0.01, * * * p<0.001$

14 Owing to data usage conditions, we cannot show these results here as they may allow identification of particular cities and universities. 


\subsection{Multivariate Results: Labour Market Participation}

In our multivariate analyses, we run separate models for all three labour market indicators. First, we report our model for student labour market participation in Tab. 3 and 4 . In the first model, we include parental class position, all three local labour market characteristics and several control variables (Model 1). We then add interactions of the main micro-level variable, parents' class position, with each macrolevel indicator in the three subsequent models (Model 1a-1c). We run the analyses using the 2000/2001 and 2003/2004 waves (subsample 2000/2003) only, as we will continue our analyses of field-related jobs with this sample in Sect. Multivariate Results: Job Quality. Results are shown in Tab. 3. We re-estimate all analyses of Tab. 3 with a pooled dataset up until the latest wave, 2015/2016 (all waves) to replicate the analyses including more recent student data. Results are shown in Tab. 4.

Table 4 Student labour market participation-all waves. (Source: Student Survey Konstanz, 2000/2001, 2003/2004, 2006/2007, 2009/2010, 2012/2013, 2015/2016 waves; own calculations)

\begin{tabular}{|c|c|c|c|c|}
\hline & Model 1 & Model 1a & Model 1b & Model 1c \\
\hline \multicolumn{5}{|c|}{ Parents' occupational status (ref-parents: service class) } \\
\hline Parents: working class & -0.00 & -0.00 & -0.00 & 0.00 \\
\hline Parents: intermediate class & 0.01 & 0.01 & 0.01 & 0.01 \\
\hline \multicolumn{5}{|l|}{ Local labour market characteristics } \\
\hline Unemployment rate & $-0.00^{*}$ & $-0.00^{+}$ & - & - \\
\hline Students/working population & -0.08 & - & -0.08 & - \\
\hline Marginal employment/students & 0.00 & - & - & 0.02 \\
\hline \multicolumn{5}{|l|}{ Interaction: local context ${ }^{*}$ parents' class } \\
\hline $\begin{array}{l}\text { Unemployment rate* working class par- } \\
\text { ents }\end{array}$ & - & 0.00 & - & - \\
\hline $\begin{array}{l}\text { Unemployment rate* intermediate class } \\
\text { parents }\end{array}$ & - & 0.00 & - & - \\
\hline $\begin{array}{l}\text { Students/working population* working } \\
\text { class parents }\end{array}$ & - & - & 0.08 & - \\
\hline $\begin{array}{l}\text { Students/working population* intermedi- } \\
\text { ate class parents }\end{array}$ & - & - & 0.07 & - \\
\hline Marginal/students* working class parents & - & - & - & -0.04 \\
\hline $\begin{array}{l}\text { Marginal/students* intermediate class } \\
\text { parents }\end{array}$ & - & - & - & -0.01 \\
\hline Constant & $0.46^{* * *}$ & $0.46^{* * *}$ & $0.46^{* * *}$ & $0.46^{* * *}$ \\
\hline Var (parental status) & 0.00 & 0.00 & 0.00 & 0.00 \\
\hline Var (residual) & 0.22 & 0.22 & 0.22 & 0.22 \\
\hline
\end{tabular}

Two-level random intercept linear probability model, random slopes for parents' occupational status Level 1: cities at time points $\left(N_{1}=113\right)$, level 2: students $\left(N_{2}=31,489\right)$

Models also include gender, age, marital status, children, school grades, the type of school leaving certificate, studying in the first or second tier of higher education, field of study, number of semesters, previous vocational training and previous work experience

Full estimated results are presented in Tab. 7 in the Appendix

$+p<0.1,{ }^{*} p<0.05$, ** $p<0.01, * * * p<0.001$ 
Table 5 Working students' job quality. (Source: Student Survey Konstanz, 2000/2001 and 2003/2004 waves; own calculations)

\begin{tabular}{|c|c|c|c|c|}
\hline & Model 2 & Model 2a & Model 2b & Model 2c \\
\hline \multicolumn{5}{|c|}{ Parents' occupational status (ref: parents service class) } \\
\hline Parents: working class & $-0.08^{* * *}$ & $-0.08^{* * *}$ & $-0.08^{* * *}$ & $-0.08^{* * *}$ \\
\hline Parents: intermediate class & $-0.03^{*}$ & $-0.03^{*}$ & $-0.03^{*}$ & $-0.03^{*}$ \\
\hline \multicolumn{5}{|l|}{ Local labour market characteristics } \\
\hline Unemployment rate & $-0.01^{* * *}$ & $-0.01^{* * *}$ & - & - \\
\hline Students/working population & $-0.30^{* *}$ & - & -0.09 & - \\
\hline Marginal employment/students & $-0.05^{*}$ & - & - & -0.02 \\
\hline \multicolumn{5}{|l|}{ Interaction: local context ${ }^{*}$ parents' class } \\
\hline $\begin{array}{l}\text { Unemployment rate* working class par- } \\
\text { ents }\end{array}$ & - & 0.01 & - & - \\
\hline $\begin{array}{l}\text { Unemployment rate* intermediate class } \\
\text { parents }\end{array}$ & - & 0.00 & - & - \\
\hline $\begin{array}{l}\text { Students/working population* working } \\
\text { class parents }\end{array}$ & - & - & 0.25 & - \\
\hline $\begin{array}{l}\text { Students/working population* intermedi- } \\
\text { ate class parents }\end{array}$ & - & - & 0.07 & - \\
\hline Marginal/students* working class parents & - & - & - & $-0.12^{+}$ \\
\hline $\begin{array}{l}\text { Marginal/students* intermediate class } \\
\text { parents }\end{array}$ & - & - & - & -0.00 \\
\hline Constant & $0.70^{* * * *}$ & $0.71^{* * * *}$ & $0.70^{* * * *}$ & $0.70^{* * * *}$ \\
\hline Var (parental status) & 0.00 & 0.00 & 0.00 & 0.00 \\
\hline Var (residual) & 0.21 & 0.21 & 0.21 & 0.21 \\
\hline
\end{tabular}

Two-level random intercept linear model, random slopes for parents' occupational status

Only employed students are included

Level 1: cities at time points $\left(N_{1}=40\right)$, level 2: students $\left(N_{2}=6687\right)$

Models also include gender, age, marital status, children, school grades, the type of school-leaving certificate, studying in the first or second tier of higher education, field of study, number of semesters, previous vocational training and previous work experience

Full estimation results are presented in Tab. 8 in the Appendix

$+p<0.1, * p<0.05, * * p<0.01, * * * p<0.001$

Tables 3 and 4 only show the results for our two main independent variables: parents' occupational status and local labour market conditions. Results of the full models, including all covariates, are shown in Tab. 6 and 7 in the Appendix.

Confirming previous descriptive studies, we find that parental class background does not significantly affect the probability that students work when controlling for the various variables on the individual level and for the context variables. This holds true for the older waves in 2000/2001 and 2003/2004 as well as for the pooled dataset of all waves from 2000/2001 until 2015/2016. Regarding local labour market characteristics, we see that the local unemployment rate significantly influences student employment. An increase in the unemployment rate by one percentage point leads to a decrease in student labour market participation by one percentage point for the subsample 2000/2003, but less than one percentage point for the pooled data. Neither the ratio of students to working population nor the ratio of marginal jobs to the number of students has a significant impact on the probability of being employed. 
The tendency is that the more students there are in relation to the working population, the lower the level of student labour market participation, whereas a lower ratio of marginal jobs to students is associated with less student employment. These findings tentatively suggest that local labour market contexts affect students' participation in the labour market.

We now turn to our "labour market hypothesis" and model the interaction of local labour market characteristics with social background to find out whether students from different social origins react differently to local labour market conditions by including interaction terms between the different local labour market characteristics and parents' occupational status (models 1a-1c). We find similar patterns in Tab. 3 and 4. While the unemployment rate still influences students' probability of employment, contrary to our expectations, the interaction terms are very small and not significant, suggesting that the relationship between local unemployment rates and student employment is independent of social class backgrounds. The picture looks different for the other two macro-level indicators (models 1b and 1c) for both samples. The proportion of students to the working population is associated with a higher share of employment for students with working- and intermediateclass parents, whereas service-class students work less often in contexts that are "crowded" with students. Although the conventional criteria of statistical significance are not met by all coefficients, this pattern in tendency supports our labour market hypothesis that inequalities are larger in labour markets with an excessive supply of students. With a higher ratio of marginal jobs to students, employment rates increase, but less so for students with working- and intermediate-class parents. The pattern of coefficients is again consistent with our hypothesis: the more jobs available, the weaker the link between working and social origin. Even though, once again, not all coefficients are statistically significant at a conventional level, we argue that a focus on a $p$ value of 0.05 would be an inadequate reduction of our results (Wasserstein and Lazar 2016). While our analyses do provide tentative support for the hypothesis that the impact of differences in local labour market structure differs between students from different class backgrounds, they also show that the effect is not very strong in size and cannot be found for every indicator we used to model the labour market structure.

\subsection{Multivariate Results: Job Quality}

In a second set of models, we examined the relationship between job content and field of study: results are shown in Tab. 5. Information about job content was only available in the 2000/2001 and 2003/2004 waves. Only working students are included in this series of models, and only coefficients for parents' occupational status and local labour market conditions are reported. The full models are documented in Tab. 8 in the Appendix.

Unlike the influence of social origin on student employment rates, social origin is significantly associated with the quality of students' jobs. Students with parents from the intermediate class or from the working class are significantly less likely to work in high-quality jobs compared with those with service-class parents, which supports our "social origin hypothesis". The results also partly support our expectations 
regarding local labour market conditions. In contexts with a high unemployment rate, job quality is lower on average. In a highly competitive situation, low-quality employment is more often accepted. This is also the case for the labour market structure, as indicated by the negative estimate of marginal employment per student and the ratio of students to the working population. The more marginal jobs that are available and the higher the ratio of students to the working population, the higher the probability of students getting a high-quality job that is related to their field of study, i.e. the more students can obtain high-quality jobs.

The interaction models $2 \mathrm{a}-2 \mathrm{c}$ show that job quality follows a similar pattern to employment. Contrary to our expectation, students from different backgrounds do not seem to react differently to unemployment rates. Although the effect sizes for the ratio of students to working population are again rather large, the association is positive for working- and intermediate-class students, but negative for students from the service class. The results for the ratio of marginal jobs to number of students again shows the most straightforward support for our theoretical expectations. Students with working-class parents are less likely to work in high-quality jobs when the ratio of marginal jobs to number of students decreases compared with students from the service class.

\section{Summary and Conclusions}

This article examines whether students' employment is related to their social origin and how this relationship is conditioned by the local labour market context. Whereas previous research often assumed that students choose whether they work or not and that social differences are mainly due to different needs and incentives, we extended this perspective by taking into account external opportunities and restrictions in this choice shaped by local labour market conditions, for instance, influencing competition for jobs among students. Besides the question of whether students work or not, we look at inequalities in job quality according to students' social background.

Summing up our main findings, social origin does not influence student employment rates per se, but it makes a difference in terms of the quality of students' jobs. This is in line with previous descriptive German studies (e.g. Middendorff et al. 2017) and shows that their findings remain valid when including a range of important control variables. Nevertheless, we found clear support for our "social origin hypothesis" that, among students with jobs, those from less privileged backgrounds are more likely to have jobs unrelated to their field of study, i.e. they have jobs of lower quality.

The main contribution of our study in both theoretical and empirical terms is the consideration of the local labour market, showing that student employment patterns depend on local opportunities and conditions. We find that fewer students work and that fewer students of those employed are in high-quality jobs in cities with a high overall unemployment rate. Hence, students as potential employees are affected by tight labour markets. Our results also tentatively indicate that students from different social origins react in different ways to the availability of jobs in the vicinity of universities, with some limitations regarding statistical significance 
at conventional levels. Students from privileged class backgrounds withdraw from the labour market when jobs are scarce, whereas lower-class students still work. Possibly, jobs in these environments involve disadvantages that employers can only impose if there is an excess supply of students seeking work, e.g. low wages, long working hours or less flexibility (e.g. Jacob et al. 2018). As such, job conditions are more likely to have a negative impact on academic success in higher education (Creed et al. 2015); they might be an important but previously overlooked dimension of educational inequality. In addition, positive effects of qualifications from highquality student jobs on labour market opportunities upon graduation (Passaretta and Triventi 2016; Sanchez-Gelabert et al. 2017) may represent another dimension of inequality. As students from privileged backgrounds are more likely to benefit from such qualification-related returns, intergenerational inequalities can be perpetuated, allowing social differentiation among graduates from higher education in recruitment to high-status jobs.

Although we control important confounding variables on both the macro and the micro level, a few limitations should be mentioned that might influence our results. First, we were not able to analyse if students live with their parents and are thus less dependent on the labour market for financing their studies (assuming that students do not have to pay market-level rent to their parents). However, in an analysis of students' budgets, Brandt and Apolinarski (2018) show that the general inequalities and dependencies on labour income are similar among both groups. Students who still live with their parents are in fact slightly more likely to report income from employment than students who have already left the parental home (67\% vs 62\%). The median employment income of those living with their parents is even slightly higher than for those who are not. Hence, this mechanism would seem to increase rather than reduce inequalities; staying at the parental home might offer poorer students an opportunity to complete their studies, but it does not avoid the previously described social inequalities in student employment patterns. However, in order to draw such a conclusion, further research is needed.

Selection processes in the form of students from particular social backgrounds or who are interested in finding a student job moving to specific cities for their studies would potentially undermine our analysis. However, empirical evidence of social differences in the distance moved for enrolment into higher education-as an indicator of social differences in choice of university location-is inconclusive. Spiess and Wrohlich (2010) do not find any significant effect for the interaction of parental background and distance from the family home, i.e. students from lower classes are as likely to move as students from higher classes. Finger's (2016) findings regarding the enrolment intentions of students in Berlin one year before attaining the Abitur (upper secondary school leaving certificate) also show no difference in terms of distance in the choice of institutions for students with parents from different educational backgrounds. Both Spiess and Wrohlich (2010) and Finger (2016) offer BAföG regulations as an explanation for their findings, with students from less affluent backgrounds eligible for additional support to cover housing costs. Hence, if we assume that students from lower classes are less likely to move out of the parental home and those that do receive additional support, their (overall) employment rate should be lower. On average, our results indicate that this is not 
the case. Let us now assume that students from lower classes generally avoid moving to university cities with high living costs and that the few who do have to work to cover their living expenses. This would mean that social differences in employment would be particularly large when jobs are available and accessible, leading to the opposite of our finding that social disparities in employment are particularly large in tight labour markets. Thus, it is possible that we underestimate the effects of local labour market conditions to some degree, but it is unlikely that the effect is reversed.

Moreover, we rely on a number of assumptions regarding our operationalisations and the quality of the data. While most variables on the individual level can be measured directly or by applying established concepts, the measurements of the macro-indicators for the labour market have to rely on the assumption that the student labour market has some overlap with the general labour market, or rather with the general market for casual labour. If a student labour market exists that is, at least to some extent, independent from the broader labour market-we will not be able to take the dynamics within this niche into account. This was one of the reasons for our decision to exclude positions as teaching or research assistants at the university from the analysis, as they are the result of a specific labour market demand that is directly created by universities. Beyond that, further research might be helpful in order to analyse when employers decide to rely on students instead of more permanent employees. Regarding data quality, one criticism might be a general scepticism towards mail surveys due to the low degree of researcher control and the low response rates. Newer methodological developments, such as the availability of large panel studies or big data, for example, from job search platforms that focus on student labour markets, offer potential for further research.

Our finding that there are local variations in employment structures for higher education students has implications for the design of policies to promote equality of opportunity in higher education. In particular, economically weaker regions might not be able to supply students with a sufficient number of high-quality jobs, meaning that lower-class students are forced to accept less attractive work that interferes with their studies. Measures to create more high-quality student jobs would be one possible approach to reducing this inequality, e.g. by funding universities to provide more on-campus jobs or supporting active collaboration between universities and local firms in the creation of study-relevant jobs. Alternatively, more generous financial support would enable all students to only work if they find jobs with qualification-related returns and might help to reduce the social inequalities imposed by the local labour market.

Funding Open Access funding provided by Projekt DEAL.

Open Access This article is licensed under a Creative Commons Attribution 4.0 International License, which permits use, sharing, adaptation, distribution and reproduction in any medium or format, as long as you give appropriate credit to the original author(s) and the source, provide a link to the Creative Commons licence, and indicate if changes were made. The images or other third party material in this article are included in the article's Creative Commons licence, unless indicated otherwise in a credit line to the material. If material is not included in the article's Creative Commons licence and your intended use is not permitted by statutory regulation or exceeds the permitted use, you will need to obtain permission directly from the copyright holder. To view a copy of this licence, visit http://creativecommons.org/licenses/by/4. $0 \%$. 


\section{Appendix}

Table 6 Full models for Table 3: student labour market participation-the 2000/2001 and 2003/2004 waves. (Source: Student Survey Konstanz, the 2000/2001 and 2003/2004 waves; own calculations)

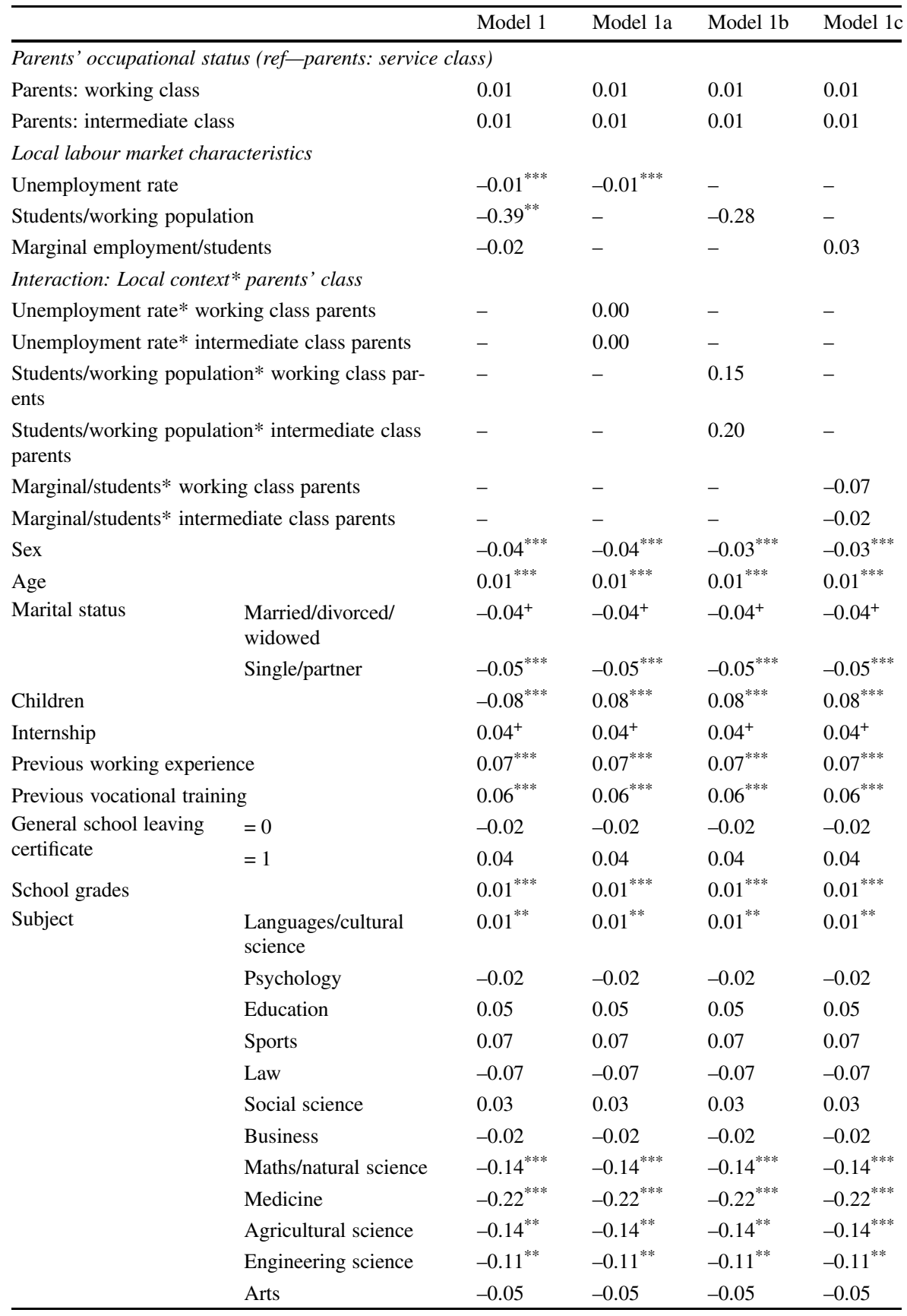


Table 6 (Continued)

\begin{tabular}{lllll}
\hline & Model 1 & Model 1a & Model 1b & Model 1c \\
\hline Number of semesters & $0.01^{* * *}$ & $0.01^{* * *}$ & $0.01^{* * *}$ & $0.01^{* * *}$ \\
University & -0.00 & -0.00 & 0.00 & -0.00 \\
Local rent rate & 0.00 & 0.01 & $0.02^{* * *}$ & $0.02^{* * *}$ \\
Constant & $0.53^{* * *}$ & $0.54^{* * *}$ & $0.53^{* * *}$ & $0.53^{* * *}$ \\
Standard deviation, constant & 0.04 & 0.04 & 0.04 & 0.04 \\
Standard deviation, residual & $0.46^{* * *}$ & $0.46^{* * *}$ & $0.46^{* * *}$ & $0.46^{* *}$ \\
\hline
\end{tabular}

Two-level random intercept linear probability model, random slopes for parents occupational status Level 1: cities at time points $\left(N_{1}=40\right)$, level 2: students $\left(N_{2}=13,721\right)$

$+p<0.1,{ }^{*} p<0.05, * * p<0.01, * * * p<0.001$

Table 7 Full models for Table 4: student labour market participation-all waves. (Source: Student Survey Konstanz, 2000/2001, 2003/2004, 2006/2007, 2009/2010, 2012/2013, 2015/2016 waves; own calculations.)

\begin{tabular}{|c|c|c|c|c|c|}
\hline \multirow{2}{*}{\multicolumn{6}{|c|}{$\begin{array}{l}\text { Model } 1 \\
\text { Parents' occupational status (ref-parents: service class) }\end{array}$}} \\
\hline & & & & & \\
\hline & -0.00 & -0.00 & -0.00 & 0.00 \\
\hline \multicolumn{2}{|l|}{ Parents: intermediate class } & 0.01 & 0.01 & 0.01 & 0.01 \\
\hline \multicolumn{6}{|c|}{ Local labour market characteristics } \\
\hline \multicolumn{2}{|l|}{ Unemployment rate } & $-0.00^{*}$ & $-0.00^{*}$ & - & - \\
\hline \multicolumn{2}{|c|}{ Students/working population } & -0.08 & - & -0.08 & - \\
\hline \multicolumn{2}{|c|}{ Marginal employment/students } & -0.00 & - & - & 0.02 \\
\hline \multicolumn{6}{|c|}{ Interaction: local context ${ }^{*}$ parents' class } \\
\hline \multicolumn{2}{|c|}{ Unemployment rate* working class parents } & - & 0.00 & - & - \\
\hline \multicolumn{2}{|c|}{ Unemployment rate* intermediate class parents } & - & 0.00 & - & - \\
\hline \multicolumn{2}{|c|}{$\begin{array}{l}\text { Students/working population* working class par- } \\
\text { ents }\end{array}$} & - & - & 0.08 & - \\
\hline \multicolumn{2}{|c|}{$\begin{array}{l}\text { Students/working population* intermediate class } \\
\text { parents }\end{array}$} & - & - & 0.07 & - \\
\hline \multicolumn{2}{|c|}{ Marginal/students* working class parents } & - & - & - & -0.04 \\
\hline \multicolumn{2}{|c|}{ Marginal/students* intermediate class parents } & - & - & - & -0.01 \\
\hline \multicolumn{2}{|l|}{ Sex } & $-0.05^{* * *}$ & $-0.05^{* * *}$ & $-0.05^{* * *}$ & $-0.05^{* * *}$ \\
\hline \multicolumn{2}{|l|}{ Age } & $-0.02^{* * *}$ & $-0.02^{* *}$ & $-0.02^{* * *}$ & $-0.02^{* * *}$ \\
\hline \multirow[t]{2}{*}{ Marital status } & $\begin{array}{l}\text { Married/divorced/ } \\
\text { widowed }\end{array}$ & $-0.05^{* *}$ & $-0.05^{* *}$ & $-0.05^{* *}$ & $-0.05^{* *}$ \\
\hline & Single/partner & $0.06^{* * *}$ & $0.06^{* * *}$ & $0.06^{* * *}$ & $0.06^{* * *}$ \\
\hline \multicolumn{2}{|l|}{ Children } & $-0.08^{* * * *}$ & $-0.08^{* * * *}$ & $-0.08^{* * *}$ & $-0.08^{* * *}$ \\
\hline \multicolumn{2}{|l|}{ Internship } & $0.03^{*}$ & $0.03^{*}$ & $0.03^{*}$ & $0.03^{*}$ \\
\hline \multicolumn{2}{|c|}{ Previous working experience } & 0.02 & 0.02 & 0.02 & 0.02 \\
\hline \multicolumn{2}{|c|}{ Previous vocational training } & $0.06^{* * *}$ & $0.06^{* * *}$ & $0.06^{* * *}$ & $0.06^{* * * *}$ \\
\hline \multirow{2}{*}{$\begin{array}{l}\text { General school leaving } \\
\text { certificate }\end{array}$} & $=0$ & -0.00 & -0.00 & -0.00 & -0.00 \\
\hline & $=1$ & $0.04^{*}$ & $0.04^{+}$ & $0.04^{*}$ & $0.04^{*}$ \\
\hline
\end{tabular}


Table 7 (Continued)

\begin{tabular}{|c|c|c|c|c|c|}
\hline & & Model 1 & Model 1a & Model 1b & Model 1c \\
\hline School grades & & $0.02^{* * *}$ & $0.02^{* * * *}$ & $0.02^{* * *}$ & $0.02^{* * *}$ \\
\hline \multirow[t]{12}{*}{ Subject } & $\begin{array}{l}\text { Languages/cultural } \\
\text { science }\end{array}$ & 0.03 & 0.02 & 0.03 & 0.03 \\
\hline & Psychology & 0.00 & 0.00 & 0.00 & 0.00 \\
\hline & Psychology & $0.07^{*}$ & $0.07^{*}$ & $0.07^{*}$ & $0.07^{*}$ \\
\hline & Sports & $0.07^{*}$ & $0.07^{*}$ & $0.07^{*}$ & $0.07^{*}$ \\
\hline & Law & -0.05 & -0.05 & -0.04 & -0.04 \\
\hline & Social science & $0.05^{+}$ & $0.05^{+}$ & $0.05^{+}$ & $0.05^{+}$ \\
\hline & Business & 0.01 & 0.01 & 0.01 & 0.01 \\
\hline & Maths/natural science & $-0.11^{* * *}$ & $-0.11^{* * *}$ & $-0.11^{* * *}$ & $-0.11^{* * *}$ \\
\hline & Medicine & $-0.20^{* * *}$ & $-0.20^{* * *}$ & $-0.20^{* * *}$ & $-0.20^{* * *}$ \\
\hline & Agricultural science & $-0.11^{* *}$ & $-0.11^{* *}$ & $-0.11^{* *}$ & $-0.11^{* * *}$ \\
\hline & Engineering science & $-0.08^{* *}$ & $-0.08^{* *}$ & $-0.08^{* *}$ & $-0.08^{* *}$ \\
\hline & Arts & 0.00 & 0.00 & 0.00 & 0.00 \\
\hline Number of semesters & & $0.01^{* * *}$ & $0.01^{* * *}$ & $0.01^{* * *}$ & $0.01^{* * *}$ \\
\hline University & & $0.04^{* * *}$ & $0.05^{* * *}$ & $0.05^{* * *}$ & $0.05^{* * *}$ \\
\hline Local rent rate & & $0.01^{* * *}$ & $0.02^{* * *}$ & $0.02^{* * *}$ & $0.02^{* * *}$ \\
\hline Constant & & $0.46^{* * *}$ & $0.46^{* * *}$ & $0.46^{* * *}$ & $0.46^{* * *}$ \\
\hline Var (parental status) & & 0.00 & 0.00 & 0.00 & 0.00 \\
\hline Var (residual) & & 0.22 & 0.22 & 0.22 & 0.22 \\
\hline
\end{tabular}

Two-level random intercept linear model, random slopes for parents' occupational status Level 1: cities at time points $\left(N_{1}=40\right)$, level 2: students $\left(N_{2}=31,489\right)$

$+p<0.1, * p<0.05, * * p<0.01, * * * p<0.001$

Table 8 Full models for Table 5: working students' job quality-2000/2001 and 2003/2004 waves. (Source: Student Survey Konstanz, 2000/2001 and 2003/2004 waves; own calculations)

\begin{tabular}{|c|c|c|c|c|}
\hline & Model 1 & Model 1a & Model 1b & Model 1c \\
\hline \multicolumn{5}{|c|}{ Parents' occupational status (ref-parents: service class) } \\
\hline Parents: working class & $-0.08^{* * *}$ & $-0.08^{* * *}$ & $-0.08^{* * *}$ & $-0.08^{* * *}$ \\
\hline Parents: intermediate class & $-0.03^{*}$ & $-0.03^{*}$ & $-0.03^{*}$ & $-0.03^{*}$ \\
\hline \multicolumn{5}{|l|}{ Local labour market characteristics } \\
\hline Unemployment rate & $-0.01^{* * *}$ & $-0.01^{* * *}$ & - & - \\
\hline Students/working population & $-0.30^{* *}$ & - & -0.09 & - \\
\hline Marginal employment/students & $-0.05^{*}$ & - & - & -0.02 \\
\hline \multicolumn{5}{|l|}{ Interaction: local context* parents' class } \\
\hline Unemployment rate* working class parents & - & 0.01 & - & - \\
\hline Unemployment rate* intermediate class parents & - & 0.00 & - & - \\
\hline $\begin{array}{l}\text { Students/working population* working class par- } \\
\text { ents }\end{array}$ & - & - & 0.25 & - \\
\hline $\begin{array}{l}\text { Students/working population* intermediate class } \\
\text { parents }\end{array}$ & - & - & 0.07 & - \\
\hline Marginal/students* working class parents & - & - & - & $-0.12^{+}$ \\
\hline Marginal/students* intermediate class parents & - & - & - & -0.00 \\
\hline Sex & $0.08^{* * *}$ & $0.08^{* * *}$ & $0.09^{* * *}$ & $0.09^{* * *}$ \\
\hline Age & $0.01^{* * *}$ & $0.01^{* * * *}$ & $0.01^{* * *}$ & $0.01^{* * *}$ \\
\hline
\end{tabular}


Table 8 (Continued)

\begin{tabular}{|c|c|c|c|c|c|}
\hline \multirow{3}{*}{$\overline{\text { Marital status }}$} & & Model 1 & Model 1a & Model 1b & Model 1c \\
\hline & $\begin{array}{l}\text { Married/divorced/ } \\
\text { widowed }\end{array}$ & 0.04 & 0.04 & 0.04 & 0.04 \\
\hline & Single/partner & $0.03^{*}$ & $0.03^{*}$ & $0.03^{*}$ & $0.03^{*}$ \\
\hline \multicolumn{2}{|l|}{ Children } & -0.01 & -0.01 & -0.02 & -0.02 \\
\hline \multicolumn{2}{|l|}{ Internship } & 0.04 & 0.04 & $0.04^{+}$ & $0.04^{+}$ \\
\hline \multicolumn{2}{|c|}{ Previous working experience } & 0.00 & 0.00 & 0.00 & 0.00 \\
\hline \multicolumn{2}{|c|}{ Previous vocational training } & $0.05^{* * *}$ & $0.05^{* *}$ & $0.05^{* * *}$ & $0.05^{* * *}$ \\
\hline \multirow{2}{*}{$\begin{array}{l}\text { General school leaving } \\
\text { certificate }\end{array}$} & $=0$ & -0.01 & -0.01 & -0.01 & -0.01 \\
\hline & $=1$ & 0.03 & 0.02 & 0.02 & 0.03 \\
\hline \multicolumn{2}{|l|}{ School grades } & $-0.04^{* * *}$ & $-0.05^{* * *}$ & $-0.04^{* * *}$ & $-0.04^{* * *}$ \\
\hline \multirow[t]{12}{*}{ Subject } & $\begin{array}{l}\text { Languages/cultural } \\
\text { science }\end{array}$ & $-0.10^{*}$ & $-0.11^{*}$ & $-0.10^{*}$ & $-0.10^{*}$ \\
\hline & Psychology & -0.07 & -0.08 & -0.07 & -0.07 \\
\hline & Education & -0.02 & -0.02 & -0.02 & -0.01 \\
\hline & Sports & 0.03 & 0.02 & 0.03 & 0.03 \\
\hline & Law & $-0.20^{* * * *}$ & $-0.20^{* * *}$ & $-0.19^{* * *}$ & $-0.19^{* * *}$ \\
\hline & Social science & -0.06 & -0.06 & -0.06 & -0.06 \\
\hline & Business & 0.05 & 0.05 & 0.05 & 0.05 \\
\hline & Maths/natural science & $-0.14^{* *}$ & $-0.14^{* *}$ & $-0.13^{* *}$ & $-0.13^{* *}$ \\
\hline & Medicine & -0.03 & -0.03 & -0.02 & -0.02 \\
\hline & Agricultural science & -0.02 & -0.03 & -0.02 & -0.02 \\
\hline & Engineering science & $-0.12^{*}$ & $-0.12^{*}$ & $-0.11^{*}$ & $-0.11^{*}$ \\
\hline & Arts & -0.08 & -0.08 & -0.07 & -0.07 \\
\hline \multicolumn{2}{|l|}{ Number of semesters } & $0.01^{* * * *}$ & $0.01^{* * *}$ & $0.01^{* * *}$ & $0.01^{* * *}$ \\
\hline \multicolumn{2}{|l|}{ University } & $-0.08^{* * *}$ & $-0.08^{* * *}$ & $-0.08^{* * *}$ & $-0.09^{* * *}$ \\
\hline \multicolumn{2}{|l|}{ Local rent rate } & -0.00 & 0.00 & $0.01^{* *}$ & $0.01^{* * *}$ \\
\hline \multicolumn{2}{|l|}{ Constant } & $0.70^{* * *}$ & $0.71^{* * *}$ & $0.70^{* * * *}$ & $0.70^{* * * *}$ \\
\hline \multicolumn{2}{|l|}{ Var (parental status) } & 0.00 & 0.00 & 0.00 & 0.00 \\
\hline \multicolumn{2}{|l|}{ Var (residual) } & 0.21 & 0.21 & 0.21 & 0.21 \\
\hline
\end{tabular}

Two-level random intercept linear probability model, random slopes for parents' occupational status Level 1: cities at time points $\left(N_{1}=40\right)$, level 2: students $\left(N_{2}=6687\right)$

$+p<0.1, * p<0.05, * * p<0.01, * * * p<0.001$

\section{References}

Bargel, Tino, Frank Multrus and Michael Ramm. 2005. Studiensituation und studentische Orientierungen. 9. Studiensurvey an Universitäten und Fachhochschulen. Bonn. Bundesministerium für Bildung und Forschung.

Bargel, Tino, Michael Ramm and Frank Multrus. 2003. Studiensituation und studentische Orientierungen. 8. Studiensurvey an Universitäten und Fachhochschulen. Bonn. Bundesministerium für Bildung und Forschung.

Behr, Andreas, and Katja Theune. 2016. The causal effect of off-campus work on time to degree. Education Economics 24:189-209. 
Bmbf. 2012. Neunzehnter Bericht nach $\S 35$ des Bundesausbildungsförderungsgesetzes zur Überprüfung der Bedarfssätze, Freibeträge sowie Vomhundertsätze und Höchstbeträge nach § 21 Absatz 2. Berlin. German Federal Ministry for Education and Research.

Bozick, Robert. 2007. Making It Through the First Year of College: The Role of Students' Economic Resources, Employment, and Living Arrangements. Sociology of Education 80:261-285.

Brandt, Tasso, and Beate Apolinarski. 2018. Finanzierungsstrukturen von Studierendenhaushalten. In $D i$ mensionen studentischer Vielfalt - Empirische Befunde zu heterogenen Studien- und Lebensarrangements, eds. Karsten Becker and Sonja Heißenberg, 159-195. Bielefeld: wbv.

Bundesagentur Für Arbeit. 2004. Arbeitsmarkt 2003 - Arbeitsmarktanalyse für das Bundesgebiet insgesamt, West- und Ostdeutschland. Nürnberg. Bundesagentur für Arbeit. 52.

Callender, Claire. 2008. The impact of term-time employment on higher education students' academic attainment and achievement. Journal of Education Policy 23:359-377.

Canabal, Maria. 1998. College student degree of participation in the labor force: Determinants and relationship to school performance. College Student Journal 32:597, 599.

Creed, Peter A., Jessica French and Michelle Hood. 2015. Working while studying at university: The relationship between work benefits and demands and engagement and well-being. Journal of Vocational Behavior 86:48-57.

Demeulemeester, Jean-Luc, and Denis Rochat. 2000. Labour participation of higher education students. Labour 14:503-522.

Erikson, Robert, and Jan O. Jonsson. 1996. Explaining Class Inequality in Education: The Swedish Test Case. In Can Education Be Equalized? The Swedish Case in Comparative Perspective, eds. Robert Erikson and Jan O. Jonsson, 1-63. Boulder: Westview Press.

Farkas, George. 2003. Cognitive Skills and Noncognitive Traits and Behaviors in Stratification Processes. Annual Review Sociology 29:541-562.

Finger, Claudia. 2016. Institutional constraints and the translation of college aspirations into intentions-Evidence from a factorial survey. Research in Social Stratification and Mobility 46:112-128. http://www.sciencedirect.com/science/article/pii/S0276562416301226.

Gelman, Andrew, and Jennifer Hill. 2007. Data Analysis Using Regression and Multilevel/Hierarchical Models. Cambridge: Cambridge University Press.

Georg, Werner and Michael Ramm, Bundesministerium für Bildung und Forschung (BMBF), Bonn, Berlin (2018): Studiensituation und studentische Orientierungen (Studierenden-Survey) Kumulation 1983-2016. GESIS Datenarchiv, Köln. ZA5675 Datenfile Version 2.0.0, https://doi.org/10.4232/1. 12974.

Hartwig, Sylvia. 2006. Funding Systems and Their Effects on Higher Education Systems. Country Study Germany. OECD, Imhe \& Bavarian State Institute for Higher Education Research and Planning, München. https://www.oecd.org/germany/38308008.pdf

Hillmert, Steffen, and Marita Jacob. 2010. Selections and Social Selectivity on the Academic Track: A Life-Course Analysis of Educational Attainment in Germany. Research in Social Stratification and Mobility 28:59-76.

Hornbostel, Stefan. 2001. Third party funding of German universities. An indicator of research activity? Scientometrics 50:523-537.

Hovdhaugen, Elisabeth. 2015. Working while studying: the impact of term-time employment on dropout rates. Journal of Education and Work 28:631-651.

Jacob, Marita, Maria Gerth and Felix Weiss. 2018. Student employment: Social differentials and fieldspecific developments in higher education. Journal of Education and Work 31:87-108.

Mayer, Karl Ulrich, Walter Müller and Reinhard Pollak. 2007. Germany: Institutional Change and Inequalities of Access in Higher Education. In Stratification in Higher Education: A Comparative Study, eds. Richard Arum, Adam Gamoran and Yossi Shavit, 241-265. Palo Alto: Stanford University Press.

Metcalf, Hilary. 2003. Increasing Inequality in Higher Education: The role of term-time working. Oxford Review of Education 29:315-329.

Middendorff, Elke, Beate Apolinarski, Karsten Becker, Philipp Bornkessel, Tasso Brandt, Sonja Heißenberg and Jonas Poskowsky. 2017. Die wirtschaftliche und soziale Lage der Studierenden in Deutschland 2016. Berlin. Bundesministerium für Bildung und Forschung. 21.

Mood, Carina. 2010. Logistic Regression: Why We Cannot Do What We Think We Can Do, and What We Can Do About It. European Sociological Review 26:67-82.

Moreau, Marie-Pierre, and Carole Leathwood. 2006. Balancing paid work and studies: working (-class) students in higher education. Studies in Higher Education 31:23-42.

Mouw, Ted. 2006. Estimating the Causal Effect of Social Capital: A Review of Recent Research. Annual Review of Sociology 32:79-102. 
Multrus, Frank. 2016. Der Studierendensurvey. Konzept, Aufbau und theoretische Grundlagen. Arbeitsgruppe Hochschulforschung, Universität Konstanz.

Neyt, Brecht, Eddy Omey, Dieter Verhaest and Baert Stijn. 2017. Does Student Work Really Affect Educational Outcomes? A Review of the Literature. IZA Discussion Paper. Bonn. IZA-Institute for the future of the study of labor. 11023.

Nienhüser, Werner. 2001. Studentische Erwerbstätigkeit und Probleme im Studium - Eine empirische Analyse geschlechtsspezifischer Unterschiede. Diskussionsbeiträge aus dem Frachbereich Wirtschaftswissenschaft Universität Essen. Essen. Universität Essen. 116:1-30.

Pascarella, Ernest T., and Patrick T. Terenzini. 2005. How College Affects Students—a Third Decade of Research. Hoboken, NJ: Wiley.

Passaretta, Giampero, and Moris Triventi. 2016. Work experience during higher education and post-graduation occupational outcomes: A comparative study on four European countries. International Journal of Comparative Sociology 56:232-253.

Riggert, Steven C., Mike Boyle, Joseph M. Petrosko, Daniel Ash and Carolyn Rude-Parkins. 2006. Student employment and higher education: empiricism and contradiction. Review of Educational Research 76:63-92.

Roksa, Josipa, and Melissa Velez. 2010. When studying schooling is not enough: Incorporating employment in models of educational transitions. Research in Social Stratification and Mobility 28:5-21.

Roksa, Josipa, Richard Arum and Melissa Velez. 2009. On the Boundary Between School and Work: Does Employment Hinder Cognitive Growth in Higher Education? Unpublished manuscript. University of Virginia.

Sanchez-Gelabert, Albert, Mijail Figueroa and Marina Elias. 2017. Working whilst studying in higher education: The impact of the economic crisis on academic and labour market success. European Journal of Education 52:232-245.

Scott-Clayton, Judith. 2012. What explains trends in labor supply among U.S. undergraduates? National Tax Journal 65:181-201.

Spiess, C. Katharina, and Katharina Wrohlich. 2010. Does distance determine who attends a university in Germany? Economics of Education Review 29:470-479. http://www.sciencedirect.com/science/ article/pii/S0272775709001198.

Statistische Ämter des Bundes und der Länder. 2007. Internationale Bildungsindikatoren im Ländervergleich. Wiesbaden: Statistisches Bundesamt.

Statistische Ämter des Bundes und der Länder. 2014. Internationale Bildungsindikatoren im Ländervergleich. Wiesbaden: Statistisches Bundesamt.

Stocké, Volker. 2019. The Rational Choice Paradigm in Sociology of Education. In Research Handbook on the Sociology of Education, ed. Rolf Becker, 57-68. Cheltenham, UK: Edward Elgar Publishing.

Triventi, Moris. 2014. Does working during higher education affect students' academic progression? Economics of Education Review 41:1-13.

Wasserstein, Ronald L., and Nicole A. Lazar. 2016. The ASA's Statement on p-Values: Context, Process and Purpose. The American Statistician 70:129-133.

Weiss, Felix, and Josipa Roksa. 2016. New dimensions of educational inequality: Changing patterns of combining college and work in the U.S. over time. Research in Social Stratification and Mobility 44:44-53.

Weiss, Felix, and Hanna-Marei Steininger. 2013. Educational family background and the realisation of educational career intentions: participation of German upper secondary graduates in higher education over time. Higher Education 66:189-202.

Weiss, Felix, Markus Klein and Thomas Grauenhorst. 2014. The effects of work experience during higher education on labour market entry: learning by doing or an entry ticket? Work, Employment and Society 28:788-807.

Zimmermann, Thomas. 2019. Social Influence or Rational Choice? Two Models and Their Contribution to Explaining Class Differentials in Student Educational Aspirations. European Sociological Review. https://doi.org/10.1093/esr/jcz054. 
Marita Jacob 1973, Dr. phil., professor of sociology at the Institute of Sociology and Social Psychology (ISS), University of Cologne, Germany. Research: social inequality over the life course, in particular inequalities in education, labour market and the family. Recent publications: Social Origin, Field of Study, and Graduates' Career Progression: Does Social Inequality Vary Across Different Fields? (with Markus Klein, 2019). In: British Journal of Sociology 70(5): 1850-1873, 2019. Vocational education and training in comparative perspective (with Corinna Kleinert, 2019). In: Becker, Rolf (ed.) Research Handbook on Sociology of Education. 284-307.

Maria Gerth 1989, M.A., researcher at Forschungsverbund DJI/TU Dortmund and doctoral student at the University of Cologne. Research: Inequalities in school, higher and early education; adolescent development, in particular deviance and peer influences. Publications: Student employment: social differentials and field-specific developments in higher education, Journal of Education and Work, 31(1), 2018 (with M. Jacob and F. Weiss).

Felix Weiss 1979, Dr. rer. soc., associate professor for sociology of education and quantitative methods at the Danish School of Education, Aarhus University, Denmark. Research: Sociology of Education, Social Stratification and Social Mobility, Labor Markets, Life courses. Recent publications: The rise of mental health problems, inequality and the role of job strain in Germany (2019, with Karin Schuller). Mental Health \& Prevention, 16, art. 200175. Saving some inequality for young adulthood? Social origin differences in 're'-enrollment in postsecondary education in the United States, Sweden, and Germany (2019). Comparative Sociology 18 (4), 522-565. 